\title{
Writing Indigenous Women's Lives in the Bay of Bengal: cultures of Empire in the Andaman Islands, 1789-1906 \\ Clare Anderson, University of Warwick
}

\section{Introduction}

This article centers on the lives of two indigenous women of the Andaman Islands, both of whom were known by the British as "Topsy." The East India Company established a settlement in the Andamans archipelago in the Bay of Bengal in 1789, but abandoned it within a decade in the face of devastating rates of disease. The British were more successful in 1858, when they settled the Islands as a penal colony for rebels and mutineers convicted during the great Indian revolt of 1857. At the time, there were four main population clusters of islanders, totaling around 6500 souls, and they had a reputation as fierce cannibals (which they were not.) In the years before the Indian revolt, islanders had made a series of attacks on shipwrecked or distressed vessels, and the British became concerned with their "pacification", and the protection of trade routes. In this context, the revolt was the catalyst for rather than the initial spur to colonization. ${ }^{1}$

During the early 1860s, a woman who the British called "Topsy" became an important cultural intermediary in the Andamans, moving with great skill between the penal colony and the Islands' indigenous peoples. She was even taken on a tour of Calcutta. I will use the few traces of Topsy's life that have been left in the archives to suggest the importance of taking an indigenous, and gendered, perspective on British settlement. The first part of this article is especially concerned with understanding how sexual violence against islanders informed colonial policy, and how islanders were incorporated into colonial efforts at "pacification" as well as the networks of Empire that crisscrossed the Bay of Bengal. ${ }^{2}$ Over forty years later, another islander, also called "Topsy" by the British, was employed as an ayah (nursemaid) to the family of the senior medical officer, A.R.S. Anderson. In 1906 she appeared as a witness at an extraordinary criminal trial, after an Indian convict named Puran Gore murdered the wife of the deputy superintendent, Beatrice D'Oyly. The witness statements made during Puran Gore's trial reveal much about the incorporation of islanders 
into colonial households, and they also further our understanding of colonial domesticity, and its relationship to other types of servitude.

In its interest in colonization, gender, networks of Empire, labor and domesticity, the article takes pause on the significance of the repeated naming of Andamanese women as Topsy during this period. Indeed, the British commonly gave islanders this name, including at least one other woman and a boy. ${ }^{3}$ At the time officials expressed the view that islanders had "no proper names for each other," leaving the mnemonic field wide open. ${ }^{4}$ I would like to suggest that the use of the name Topsy was rooted in Harriet Beecher Stowe's blockbuster antislavery novel Uncle Tom's Cabin; Or, Life Among the Lowly (1852). It tells the story of a slave girl named Topsy who was bought by a man called St. Clare for his cousin Miss Orphelia, who was to train her in domestic skills. Uncle Tom's Cabin was the most successful commercial novel of the nineteenth century. Translated into thirty-seven languages, over two million copies were sold in its first year of publication, and by 1878 it had been published in at least thirtyeight editions, and inspired countless dramatizations, musicals, and songs, including more than twenty different theatrical productions in London alone. Harriet Beecher Stowe achieved such fame that she even visited the White House to meet abolitionist president Abraham Lincoln. However, despite Beecher Stowe's anti-slavery intent, Uncle Tom's Cabin inspired a number of racist stereotypes in its many performative derivations. There was an especially significant interface between Uncle Tom's Cabin and minstrelsy, a popular theatrical form in which actors "blacked up" to mimic and laugh at Africans. Such ridicule included the employment of what scholar Sarah Meer has called "exaggeratedly inappropriate names for slaves that mocked their blackness," including "Snowball," which as we will see was also a name given to Andaman islanders. $^{5}$

The presence of several "Topsy"s in the Andamans, over an extended period of time, suggests that Uncle Tom's Cabin touched the furthest reaches of Empire. Indeed, we know that within a few years of its publication, the novel had reached India. Middle-class Bengalis read it, and even compared the position of Indian "coolie" tea laborers in Assam with African-American slaves. ${ }^{6}$ And, speculatively, perhaps it even found its way into the settlement library at Port 
Blair. It is of significance that during the late 1850s and 1860s it was sailors of the naval brigade who led colonial contact missions with Andamanese settlements, and who named the islanders under their charge. Though most sailors were British, the brigade included a smattering of Americans. From the diary and letters of a Bostonian sailor called Edwin Forbes, who was stationed in the Islands in the 1860s, we know that there was a library in the settlement, and that naval brigadesmen enjoyed reading aloud to each other. ${ }^{7}$ The implicit allusion to Uncle Tom's Cabin in sailors' choice of name for a woman (Topsy) would have been obvious to contemporaries.

I will close this introduction by restating a point that is important to this whole issue: writing life histories is only possible when individuals enter the pages of the colonial archive. That one of the most displaced peoples of Empire, Andaman islanders, are present in the records at all speaks to the profound impact of colonization. Nevertheless, their presence remains elusive and limited. There are no islander-generated accounts of colonialism, oral or textual. ${ }^{8}$ This means that, as for many of the men and women discussed in this collection of articles, if we are to center indigenous peoples in histories of Empire, we need to do so through the piecing together of a wide range of archival fragments. ${ }^{9}$ It is also important to recognize that biography itself as a narrative form might sit in contradistinction to nineteenth-century indigenous cosmologies and understandings of life paths. These may not have given especial meaning or narrative trajectory to the journey from birth, through life, to death. Both points are salient reminders of the difficulty or perhaps even appropriateness of writing biographically from an indigenous perspective.

\section{Indigenous interlocution in the Bay of Bengal}

In the context of their growing interest in South and Southeast Asia, the British began to take an interest in the Andamans in the 1770s. As they cruised around the Islands, on occasion survey parties touched shore to kidnap island men and women in the hope that they might learn something of their culture and language - and return to their settlements with positive accounts of their captivity. Islanders mystified the British; they looked as if they came from Africa and yet lived in an archipelago close to Burma. Inevitably perhaps the British 
came to understand and represent their supposed racial origin through a larger, imperial framework, and compared islanders to a host of other colonized peoples, including Australian Aborigines, New Zealand Maori, and Native Americans. ${ }^{10}$

We know almost nothing of colonial contact with islanders during the period of first settlement (1789-1796), but after permanent colonization in 1858, as they sought to expand the penal colony, the British made efforts to "pacify" them. They encouraged the sailors stationed in the Islands (as convict guards) to visit Andamanese settlements, to exchange foodstuffs and other small objects for items like bows, arrows, and belts. Convicts were also involved in "contact missions." Though the British warned against violence, these encounters were often aggressive. Indeed, a key moment in the colonial history of the Andamans was a sailor's attempted rape of the woman Topsy (also sometimes called "Madam Cooper") in January 1863. Two men, known to the British as "Jumbo" and "Snowball," fired an arrow at the sailor in question, James Pratt, and he later died from his injuries. Initially, the sailors covered up evidence of the sexual assault, and in the weeks before the settlement's superintendent, R.C. Tytler, discovered the islanders' real motive, he lamented their attack on Pratt as the action of "treacherous ... blood-thirsty, subtle murderers." Subsequently he directed the building of an "Andaman Home" on Ross Island, for the forced confinement, education, and industrial training of islanders. "By this means alone will this savage tribe be reclaimed to civilization," he wrote. Shortly afterwards Tytler found out about Pratt's sexual assault. However, the construction of the Home went ahead, and it opened in April 1863. Ironically enough, two of the first residents were Topsy and Jumbo, who was described as her "husband", together with Snowball and a boy the British called "Sambo." A country-born man of the cloth from Calcutta, the Reverend Henry Corbyn, was placed in charge of the islanders and, extraordinarily in a penal colony, Indian convicts were used as overseers, or parawallahs (policemen). ${ }^{11}$

The Andaman Home originated through colonial violence, and it was underpinned by continued coercion, as it sought to force islanders into relations of dependency with the colonial settlement, encouraging them to develop a taste for liquor and tobacco. Henry Corbyn attempted to "civilize" and "instruct" 
islanders in and through reading and writing, needlework and basket making. Topsy and a woman he called "Bess," like other islanders, in the face of Corbyn's slaps and beatings, at first resisted his efforts. Eventually, however, they showed what Corbyn described as "a real aptitude for delicate manual labor" such as needlework. On one occasion when he returned to the Home with a cut on his leg, he interpreted Topsy's attention as evidence of her kind and gentle character (though it might just as easily have been an attempt at good conduct with liberation in mind.) He revealed also something of the way in which they communicated - through a mixture of gesture and mime:

I was amused the other day, on returning from the woods, where I had torne my trousers, - as soon as Topsy caught sight of the rent she pointed it out to the other Andamanese women and condoling with me, as my leg was slightly cut and bleeding, neatly put the slit pieces of the cloth together and said, and shewed how when she returned to Ross Island she would get a needle and thread and stitch them. I mention these trifling points as they serve to bring more vividly before the mind's eye the movements and actions, the habits, character, and dispositions of the curious and interesting people of whom I am writing. ${ }^{12}$

But Topsy was no passive recipient of colonial discipline. Corbyn also wrote of how she had laughed in his face when she briefly left the Home and returned daubed with "paint" (likely the red clay commonly used by islanders.) Superintendent Tytler had banned this cultural practice as "degrading and barbarous", and Topsy was evidently aware that she had trumped him. ${ }^{13}$ Elsewhere I have described the Andaman Home as "a strange spectacle - a space of Andamanese experimental captivity within a place of Indian convict colonization," and noted the crowds of Indians and Europeans who came to gaze at islanders. The islanders greatly enjoyed frightening them, and learned to their delight that they could scatter the visitors left and right with their war cries. ${ }^{14}$

The British had little knowledge of Andamanese settlements, culture or language, and communication was largely effected through acting out. But this was a power-laden relationship. Corbyn wrote that during one sortie in July 1863, Topsy became "greatly distressed" when their boat passed by Ross Island, where Jumbo was being held against his will. She later took Corbyn to a carefully hidden pile of arrows, and indicated that he should take them, with words 
including "Jumbo tweeken", which he took to mean that having shown him the cache of weapons she expected to be taken back to her "husband." 15

Corbyn's description of the scene when they returned to Ross shortly afterwards is worth citing at length:

Topsy's vanity was particularly gratified by the importance which she assumed in the estimation of the audience; she told them how much her services had been in demand during the day, that some one or other was constantly calling to her "here Topsy, there Topsy, Topsy, Topsy, come Topsy" (she remembered and repeated the words), and that one person would drag her by the arm in one direction, and another in another. ${ }^{16}$

As he watched her physical movements and listened to what she said (in English at least), in his view Topsy's liaisons with the colonial settlement gave her enormous prestige. But in the absence of islander accounts of this period, beyond recognizing the importance of physical re-enactments and thinking between the cracks of snippets of reported speech, we should be wary of reading too much into Corbyn's presumptions. Certainly, the colonial officer in charge of the Andamanese later in the nineteenth century, M.V. Portman, was strongly critical of his representations and claims to understanding islanders, never failing to point out his misunderstanding of particular words and phrases. ${ }^{17}$

Corbyn's beatings in the Home, and physical threats against Jumbo, were part of a more general pattern of systematic colonial violence towards the Andamanese. ${ }^{18}$ After arrows were shot at two escaped Indian convicts in July 1863, for example, Corbyn took four islanders, including Topsy, to see the wounded men, and with a bow and arrow in his hand mimed how they had been injured. He went on:

I then pointed the pistol by turns at Jumbo, Joe, and Jacko ... and by my angry and menacing gestures making them quake with the horrible fear that their lives were in instant peril. Topsy made frantic gestures, which I understood to imply that her tribe was not at fault. ${ }^{19}$

Topsy pointed resolutely southwards, leading Corbyn to understand that another tribe was to blame. She then pointed to Jumbo's fetters. He understood that she wished him to take her to the settlement of the responsible men, so that 
he could put them in chains. "Jumbo was so agitated that he could hardly stand," Corbyn continued, "and Topsy covered him with her body to shield him from harm." He was utterly unrepentant about the dreadful effects of what he called, without irony, a "pantomime." He wrote: "I felt that it was better to cause momentary terror ... than any longer allow the lives of unoffending persons to be exposed to their cruel caprices." 20

In 1858 the survey party that had traveled to the Andamans to choose the best site for the penal colony had kidnapped a man they named "Jack Andaman," and taken him back to Calcutta. They took him to see the sights and to meet Governor-general and Lady Canning, in the hope that he would return to the Islands with positive tales of his captors. ${ }^{21}$ Subsequently, from the 1860 s on, islanders were taken on numerous overseas tours, and for exactly the same reason, visiting Calcutta, Penang and even the Nicobar Islands. Typically, they met the viceroy, were exhibited or modeled for exhibitions, and visited railways, bridges, monuments, the botanical gardens and the zoo. ${ }^{22}$

In mid-October 1863, Topsy and Jumbo, along with a man known as "Jacko" and five children, accompanied Corbyn on the first such tour since Jack's kidnap in 1858. He hoped that they might "describe to their people, on their return, the superior advantages of a civilized life." 23 The party was away for almost six weeks, returning to the capital of the colony, Port Blair, at the start of December. The local response to the islanders in Calcutta replicated in many ways Jack's reception five years' earlier, as an eager crowd gathered at the town hall, hoping for a glimpse of them. Eventually, the crowd became so large that the surrounding roads became impassable, and a frenzy of rumors began to circulate. Among these were whispers that the islanders had long tails, and that one of the women was ill and would only recover if she ate a white man's flesh. Corbyn struck a deal: he would bring the islanders out onto the steps, if the crowd would then vacate the compound. This did little to ease the congestion, and as no hoteliers would offer rooms to the islanders, the visitors moved to a temporary camp in the Ballygunge parade ground in the city's suburbs. From this base, Corbyn took the islanders to the Calcutta Mint, to a meeting of the Asiatic Society, and the Asiatic Society's Museum. They went to the piggeries of Entally, which Corbyn claimed "threw them into raptures" (islanders hunted and ate wild 
pigs); to the fort, arsenal and armory; and to the Rajah of Burdwan's house, grounds and menagerie. He recalled that their favorite place of all was Dhurrumtollah market.

When they returned home, Corbyn reported "a scene of wildest revelry" as the men, women and children sang and danced while "all of the Calcutta adventures were glowingly related." Day after day, he claimed, islanders begged him to take them to Calcutta. According to Corbyn, beyond their retelling of the wonders of the city, and their desire to return or to go to the mainland for the first time, one lasting legacy of the trip was that islanders had "a more contemptible opinion of the Natives [Indian convicts] than they had ever before entertained of them". He believed that this was because islanders viewed them as "immeasurably inferior," but it is perhaps more important that as he had previously noted on two occasions in Calcutta Indians had spat on them in the public street. ${ }^{24}$

Though we do not know how the relationship between Corbyn, Topsy and Jumbo developed during this tour to the mainland, after their return from Calcutta, Corbyn accelerated his efforts to manipulate them. Commonly, he kept Jumbo in chains in the Andaman Home, and took Topsy out on contact missions, making open threats that he would harm Jumbo if she did not assist him. ${ }^{25}$ For instance, in March 1864 superintendent Tytler began to explore the possibility of developing the colony by forming a settlement at Port Mouat, to the west of the colonial settlement at Port Blair. He dispatched an expedition, led by Corbyn and the executive engineer, and accompanied by a group of Indian convicts, as well as Topsy and Jacko, who had traveled with her to Calcutta the previous year. The day after the party set up camp, Topsy and Jacko warned Corbyn not to proceed any further. He wrote: "They made me understand that we should encounter an unfriendly tribe of aborigines of whom they themselves seemed to be in great dread." Jacko, Corbyn went on, pointed to his heart, and acted out his death at the tip of an arrow. "Topsy also pathetically enacted the death scene, and both waved their hands deprecatingly in the direction disapproved of." It was not long before the group was surrounded by two hundred islanders, their arrows raised in what Tytler later described as "a picture of savage hatred." 26 Corbyn reported that he called Topsy to him, and told her that he would have Jumbo and other 
islanders killed if misfortune fell on the party. She said: "Do not fear, they will never shoot at you, 'Myjola' (our protector),"27 and waded through the water towards the advancing party. Corbyn stayed close, so that he could seize her if she betrayed them. He went on:

I had a drawn knife in my hand, and told her that the Sailors would fire instantly if an arrow was shot. Two or three times the Andamanese stopped as in doubt and hesitation. Topsy used all her eloquence and powers of persuasion, told the Chief, who looked very much inclined to raise his bow as I approached him, that I was the "Myjolah," by which title they seemed to have heard of me and to recognize me, and with all the entreaty of gesture as well as words implored them not to shoot us, often mentioning the name of her husband and the other Andamanese, which also seemed familiar to them ... All this time they were wading through the sea towards our boat round which our party was assembled with muskets and revolvers held readily to fire upon them, while Topsy and I ... moved forward towards them. At last we met ... Topsy very dexterously seized the opportunity, threw her arms round him, took hold of his bow and arrows, and before he had time to remonstrate or prevent her, handed them to me. ${ }^{28}$

Superintendent Tytler represented Topsy's intervention as evidence of Corbyn's positive influence over islanders, though it seems equally likely that it was the outcome of his earlier threats against Jumbo and others. Whatever the case, it was at this moment that in Tytler's eyes that islanders were transformed "from formidable foes" into "our friends." Moreover, in his view, it was the "truly noble conduct" of Topsy that had saved the entire survey party from certain death. ${ }^{29}$

Just a month after this remarkable encounter, when the British hailed an island woman as their heroic savior, to Corbyn's near bafflement (and, perhaps, to our lack of surprise), almost all the islanders living in the Andaman Home on Ross Island had deserted. Corbyn found Topsy and Jumbo about to leave too, and when he dispatched boats to pick up the islanders who were swimming for the mainland, he took Topsy to North Point. He left her there, warning that if the islanders did not return to Ross the next day he would punish Jumbo - who he had left at the Home. Corbyn took her back to Ross, and then left with Jumbo, hoping to bring more islanders back. Shortly afterwards, and her archival silence speaking volumes about the relationship between coercion and colonialism, Topsy made her own bid for freedom. She walked down the beach, dived into the sea, and swam for the mainland. It is hard not to be moved by colonial reports 
that a woman's body was found in a shallow grave on South Point beach a few days later. The unfortunate Topsy had drowned. ${ }^{30}$

Corbyn's subsequent report on the reasons for the mass "escape" of islanders - "the discomforts which they have to endure, and the strong yearning which they must feel for their accustomed way of life" - was the cause of a sharp exchange of words between the Islands and the mainland. The Viceroy of India, Sir John Lawrence, warned the Andamans administration that Corbyn had been wrong to refer to their "escape," for islanders could not and should not have been forcibly detained against their will. ${ }^{31}$ Shortly afterwards, Corbyn resigned, pleading that "harassing and laborious duties" had ruined his health. Superintendent Ford received his resignation with regret, thanking him for his "successful" management of the Andamanese, as well as his "cordial, sincere, active and ready manner." There was no mention of Corbyn's blood stained hands. ${ }^{32}$

\section{Islanders, slavery and domestic servitude}

Almost thirty years later, in 1892-3, British officer in charge of the Andamanese M.V. Portman wrote that one of the Andamanese women "in service" in Port Blair, also called "Topsy," had two children by "Natives of India." This was almost certainly a reference to their convict paternity. ${ }^{33}$ He said that she lived in the compound of his house in Port Blair, her employer finding it "impossible to keep her" after she had her second child. "He had always treated her kindly," Portman noted, "but the ineradicable savage element was too much for him." ${ }^{34}$ Several Andamanese women had children with Indian convicts. We know nothing of Topsy's relationships, but more generally sailors, settlers and convicts perpetrated sexual violence against Andamanese women, and a sexual economy in which they were paid for their services developed. ${ }^{35}$

In 1883, assistant superintendent E.H. Man spoke about another woman "Ruth" - in some detail at a talk at the Royal Anthropological Society in London, in the context of a larger discussion on the Andamans orphanage. He described an educated and accomplished young woman, who had become bound up in metropolitan cultural networks: 
[She] was highly trained by Mrs. Homfray [wife of Corbyn's successor], and is able to speak, read, and write English, as well as to converse glibly in Hindustani. As she has been with us from infancy, it is hardly necessary to say that she is ignorant of her native tongue. Ruth is also an accomplished needlewoman, and is clever at making designs; she wears the European costume, not excepting bonnets and hats. Some idea of the advance she has made on her fellowcountrymen (who are still in the stone age) may be gathered from the above statements, but further proof is found in the fact of her asking for and obtaining a Christmas card album from England, and some lace for the adornment of her dresses! ${ }^{36}$

In his book on the Andamans, published shortly afterwards, he substituted Ruth's desire for an album and lace for her want of "an English dictionary, which she says she finds 'very useful' when writing her letters!" 37 It seems that Ruth had undergone extensive domestic instruction in the orphanage, including in needlework, and had learned to read and write. Like the other girls, some of her work - in Man's words "fancy articles" - was sold. Later on, she was employed as the sewing mistress at Aberdeen School. She was able to use a sewing machine and did what Portman described as "good work."38

After Mrs Homfray's death several other officers took Ruth into service. Portman noted that they all "declined to keep her for long," because "she formed liaisons with the servants in the different houses and had more than one child." She later had a daughter by a convict hospital attendant, and applied for permission to marry the man. However, the authorities turned the request down. In his annual report for 1892-3, Portman noted that she lived at Haddo, and took good care of her child who, he added, "strongly resembles a Papuan." 39 It was the following year that Portman wrote that she was living with Topsy in a small house in his compound with her child, having been dismissed from the Aberdeen School for "misconduct." He employed her in making and repairing Andamanese clothing. Her daughter was undergoing instruction in English, Hindustani and sewing. Portman noted that she could speak "more than one Andamanese dialect." 40

It was perhaps the same Topsy who was caught up in the murder of the wife of the deputy superintendent. On 26 February 1906, convict Puran Gore, registration number 26,467, killed Beatrice Alice D’Oyly (née Clerk), the wife of Hastings Hadley D'Oyly. ${ }^{41}$ The fact of Beatrice D'Oyly's death is noted in her 
entry in Burke's Peerage, ${ }^{42}$ but the circumstances of the murder are not. Her gravestone in the Andamans, however, still carries the inscription: "cruelly killed by a homicidal convict ... leaving three young children motherless." 43

The very next day, 27 February 1906, Puran Gore was brought to trial on a charge of murder. ${ }^{44}$ He said that he was 19 years old, and that he was a Hindu Gond (a large tribal group in Central India). He pleaded guilty, and offered the following motive:

I was taking water to the bath room and Mrs D'Oyly rated me, saying that the water was dirty. She said she would report me, and asked me for my number. On hearing this I went away and found a chopper, the one lying before the Court. It was lying before the cookhouse among some cooking utensils. I took this dah [chopper] and went up again to the bath room. Mrs D'Oyly was going into her room. I followed her and struck her with the dah in my hand. She tried to kick me and I struck her again. I then assaulted the ayah and the other lady in the house Mrs Anderson. The servants then came up and hit me with a lathi [cane] and I made off.

He added further details, that he had hit Beatrice D'Oyly on the head and neck; and that she had screamed. He added: "I killed Mr Williams in Assam because he beat me." On further investigation it was found that Williams had been the European foreman of the Namdang Colliery. Puran Gore had been sentenced to death for his murder in February 1904, but the High Court of Calcutta had commuted the sentence to life transportation. Justice Ameer Ali commented at the time: "Williams had caused the prisoner a susti soor [lazy pig] and struck him several times with a cane ... The accused in his statement says that the deceased used to flog him every day ... it is clear that the prisoner was to some extent goaded on to this assault on Williams." 45

Witnesses gave more information about the attack on Beatrice D'Oyly, who at the time had been enjoying the company of the wife and children of the island's senior medical officer A.R.S. Anderson. Burmese convict Nga Sein, her husband's office orderly, testified that Puran Gore had only started work - as a water carrier (bhisti) - three days earlier. Nga Sein said that he had heard screams in the house: "I ran up the stairs and saw Mrs Anderson run out of a room and accused behind her, holding a chopper (produced) in his hand uplifted. I at once struck at him with my stick ..." He hit Puran Gore twice, and 
chased him through the house. Together with another convict orderly called Shib Rath, he managed to seize hold of him and tie him up. Nga Sein said that he had asked Puran Gore why he had attacked Mrs D’Oyly, and claimed that he had replied: "she scolded me." He then asked why he had attacked Mrs Anderson, but said that Puran Gore "gave no answer." Convict Abdul Rahman, Beatrice D’Oyly's table servant (khitmutgar), also testified that he had heard screams in the house, and had run upstairs. He had heard the ayah screaming "maar diya, maar diya" ("she's dead, she's dead.") Just as Puran Gore was about to strike Mrs Anderson with his dah, Abdul Rahman stated, Nga Sein had hit him so hard that he had dropped it.

The third witness in Puran Gore's trial was Topsy. She opened her statement with three short answers to three short questions, and a longer description of her employment:

Topsy - Wife of Mopo Andamanese - Tribe or Caste: Andamanese - Residing at Aberdeen - Occupation: Andamanese ayah.

"I am Mrs Anderson's ayah, I am an Andamanese myself and the wife of Mopo Andamanese who works at Government House."

She went on to give her testimony in English, unlike the convicts who appeared during the trial. They spoke in the convict lingua franca of the Andamans, Urdu. Superintendent of convicts W.R.H. Merk noted that Topsy had spoken "very clearly ... as well as I have heard evidence given." She said that on the day of the murder Hastings D'Oyly and Beatrice's brother had been away in North Andaman. After lunch, Mrs D'Oyly, Mrs Anderson and their children had been on the veranda. Beatrice had gone inside with the children to get some sweets, together with Mrs D'Oyly's ayah, and Mrs Anderson's second ayah, a convict called Harkour. Topsy had stayed on the verandah, and was reading the newspaper, when about five minutes later she heard screams. "I saw Harkour running through the dining room, with Mrs Anderson's baby in her arms," Topsy said. "I followed behind the accused and shouted to Harkour to drop the baby, but she would not, holding him tight in her arms." It was only when Puran Gore cut her on the shoulder that she let him go. Topsy picked up the baby and ran, pursued by the convict who tried to cut the child with his dah. "I pressed it to my 
chest," Topsy said, "and the blow fell on my head." At this moment, Mrs Anderson appeared, shouting, "save my baby, he is killing the baby." Puran Gore turned and began to chase her, and Topsy saw him cut her right hand. It was at this moment that Nga Sein came and caught Puran Gore.

Mrs Anderson's husband, A.R.S. Anderson, was the senior medical officer of the Andamans. He found Beatrice D'Oyly with a six inch long wound to the head, which had cut through the skull and "penetrated deeply into the brain." She had further wounds to her neck, and had bled to death. Harkour had a serious head wound, as did Topsy. His wife had cuts to the hand, as she had raised them to defend herself. Superintendent of convicts Merk described the murder as "a dreadful business." Indian home secretary H.H. Risley added that the incident gave force to contemporary debates about the abolition of penal transportation. It was impossible, he said, to prevent attacks by convicts "prepared to be hanged" and "weary of life." Puran Gore was found guilty of murder, and shortly afterwards he was hanged at the colony's Viper Island gallows. His body was taken down and then it was burnt.

Meanwhile, home secretary Risley granted absolute release to convicts Nga Sein and Harkour, and gave them permission to return to India. He recommended the prohibition of the employment of convict murderers as servants. Chief Commissioner of the Andamans H.A. Browning pointed out, somewhat acidly, that as most convicts were murderers, this would narrow considerably "the field of selection," and that "experience has shown that murderers as servants are well behaved." It was eventually decided that convicts would no longer be employed as punkah-wallahs [fan-pullers] or bhistis, and convicts who had been transported for the murder of Europeans would not be allowed to serve as servants at all. ${ }^{46}$ It was also directed that, in future, mainland court judgments should be sent to the Andamans, to assist the local authorities in allocating convicts to labor. Indeed, it seems that the Assam authorities had not forwarded details of Puran Gore's conviction, and had they done so it was unlikely that he would have been employed as a bhisti in a colonial household. ${ }^{47}$ The newly widowed Hastings D'Oyly, meanwhile, was given a year's furlough. 48

Extraordinarily, the Indian authorities managed to keep the murder out of the Indian press. In a brief note, written two months after Beatrice D'Oyly's 
death, Risley claimed that there had been no public interest in it, and so he had not sent any details to Indian newspapers. This meant that news of the story was not picked up overseas, including in Britain, either. His refusal to release information must be viewed in both the local Andamans context, and more broadly in the context of political instability in turn-of-the-century mainland India. Towards the end of the nineteenth century, many officials - including Risley himself - believed that transportation was an inadequate punishment, a soft option courted by defendants in preference to incarceration in Indian jails. In an effort to make transportation more penal, in 1896 work began on a cellular jail modeled on Jeremy Bentham's panoptican design. A central watchtower loomed over seven three-story wings, so that inmates could never be sure if they were being watched. All newly arrived convicts were to spend a period of time there, before being sent out to labor in the colony. The jail opened just one month after Beatrice D'Oyly's death. It is hardly surprising, then, that the Andaman authorities were keen to hush up this gross breach of penal discipline. More broadly, though there was no suggestion that Puran Gore was politically motivated, likely government was aware that his attack might be interpreted as such. During the years 1899 to 1905, Viceroy Curzon had begun to restrict Indian political participation. In 1905 he had ordered the partition of Bengal, hoping to split opposition against the British through the creation of a Muslim majority province in the east. Hereafter developed the swadeshi (self-sufficiency) movement, which incorporated a range of moderate and extremist anti-colonial activities, including boycotts of British goods as well as outright violence. ${ }^{49}$ Thus the response to Beatrice D'Oyly's murder was caught up in imperial concerns that were important in but also stretched far beyond the colonial outpost of Port Blair.

I mentioned above that the convicts who came to the assistance of Mrs D'Oyly and Mrs Anderson were given absolute pardons, and permission to return home. The pardoning of convicts for especial service was a central element of convict discipline in the colony. Topsy, however, was not a convict, but a paid servant. Risley first proposed that she be awarded the third class Indian Order of Merit medal: an eight pointed dull silver star containing a blue circle, silver laurels, crossed swords and the words "Awarded for Valour." There followed a 
debate with the mainland where it was argued that the medal could not be granted because Topsy's actions had not supported public authority or safety. This was, of course, a matter of interpretation. More significant, perhaps, was Risley's comment that the Order ought to be confined to "natives of India": "yet as we know how women are regarded by natives - especially those of low caste we should not admit her." Risley was concerned that the award would "detract from the esteem in which it is held." The government of India eventually agreed that she would be given a sewing machine and clothes to the value of 100 rupees, "bestowed with ceremony" to emphasize the special circumstances of the award.

The question of how to reward Topsy for her bravery reveals some of the fault lines around gender, race and caste. Topsy ayah's position and treatment draws attention also to the making of colonial domesticity in the Andamans. Historian Indrani Sen has, rightly, drawn attention to the somewhat ambiguous position of Indian ayahs in European households, for their close relationship with children upset colonial hierarchies in significant ways. She notes that Europeans were critical of the "caste prejudices" of their ayahs, notably their refusal to undertake certain tasks. Perhaps the employment of an Englishspeaking Andamanese woman was preferred because it circumvented such issues, as well as guarding against the supposed "danger" of raising vernacular speaking children, to which Sen also refers. ${ }^{50}$ But, clearly, there are important associations to be made also in the employment of the Andamanese - seen at the time as potentially having "racial" origins in Africa - in contexts resembling closely the "Big House" of slavery.

We know from Topsy's testimony that she was an educated woman. She spoke perfect English, she understood Urdu, and she could read well enough to peruse a newspaper. Risley added further that she was "well known and conspicuous at Port Blair," and "a very quaint personality." It might be that Topsy's novelty lay in her demonstration of the possibility of bringing islanders into the colonial fold. And yet the employment of such a socially accomplished woman within the colonial household is strongly reminiscent of the aristocratic fashion for the employment of African slaves as servants. In the years following the abolition of slavery, in the 1830s and beyond, commonly colonial households in the penal colonies of Australia expressed a strong preference for the 
employment of African, Indian and Creole ${ }^{51}$ convicts as their servants, cooks and grooms. ${ }^{52}$

To return to the issue of naming practices for a moment, historian Satadru Sen has shown that they collapsed Andaman islanders into inferior collectivities. ${ }^{53}$ His point is well made and equally well taken, but American literary allusions to enslavement are important too. In this respect it is noteworthy that the naming of Andaman islanders more generally was both like and unlike the naming of slaves. African and Creole slaves in the Americas - as well as in the Caribbean and western Indian Ocean - were often named from the Bible or classical literature. Sometimes slave owners gave them demeaning names, named them after their personality, or days of the week. Thus slaves were called Jean-Baptiste [John the Baptist], Caesar (or César), Jupiter, Marie (or Mary), Mercury, Petit Jean [Little John], L'Esperance [Hope], and Sunday. If they were given common European names, they were frequently diminutive and thus infantilizing in form and intent (e.g. Bessie not Elizabeth; Dolly not Dorothy). On the Indian mainland, the British seem to have given their slaves similarly "childish" names (Tom; Dick), or names that onomatopoeically mimicked Indian ones, for instance "Nancy Burn" for "Nusseeburn." 54

Following the naming patterns of slavery, Andaman islanders were given one name only, and not the surnames that for communities in Europe and elsewhere mapped family networks and lineage. Some islanders were given colonial names that were strongly reminiscent of slavery, either through biblical reference ("Ruth"), diminutive form ("Jacko", "Joe") or mocking descriptions. The latter included the naming of Topsy's husband "Jumbo", clearly a degrading reference to his height (islanders were known to be of relatively short stature), and of another "Snowball”, an explicitly racist reference to his skin color. "Queen Vic" was likely named after Queen Victoria. But in other cases the naming of Andaman Islanders was inspired by literature, and this was quite unlike slave onomastics. Thus we can trace islanders "Crusoe" and "Friday" to Daniel Defoe's enormously popular castaway novel Robinson Crusoe (1719), which sees the hero shipwrecked on a remote tropical island. "Sambo" was a common slave name in the Americas, but a character of that name featured in Uncle Tom's Cabin, as a slave overseer, as well as in British author William Makepeace 
Thackery's Vanity Fair (1847-1848), where he appeared as a dark skinned Indian servant. Finally, as we have seen, we can locate "Topsy" as the fictional slave girl created by Harriet Beecher Stowe.

We do not have to look very far for allusions to the "Big House" of slavery in the Andamans. Assistant superintendent E.H. Man wrote in 1885 of the young men who worked as table servants:

[S] everal Andamanese lads have been taught to wait at table, and prove both useful and handy at such duties, behaving with most becoming gravity, as if, indeed, they had been to the manner born! It is a somewhat absurd sight to see these jet-black imps dressed in white, with arms crossed and heads thrown back, standing like statues behind their masters' chairs, watchful to fulfill any service required. 55

The choice of Andaman islanders as domestic servants (however "absurd" or "quaint" officers like Man and Risley found it) was part of a continued imaginative association between African slavery, servitude and the European household. In this respect, the legacies and associations of African slavery ran deep, and they were frames through which the British could represent and manage Andaman islanders. In this sense, the social intimacies of islanders nursing babies, looking after children and waiting on tables were embedded in imperial practices that reached the Andamans long after the abolition of slavery.

\section{Conclusion}

The lives of the two women Topsy who I have discussed in this article are shot through with silences and ambiguities, for they have left only the faintest biographical trace in the colonial archives. But if we are to foreground the lives of those who were dispossessed by Empire in the writing of colonial history, it is important that we square up to absences, and connect up brief archival snippets in order to lay stress on the profound and violent impact of colonization on individuals. In this respect, my broad intent has been to decolonize a colonial archive that - quite unlike the record kept for each convict in the Andamans penal colony - was not concerned with recording individual lives over time. I have sought also to write about indigenous women, and to place them at the center of analysis, without losing a sense of their limited choices and agency in 
the face of domination. Finally, in drawing multiple layers of connection between indigenous lives and the impact of colonialism - between islanders, settlers, convicts and slaves; between the Andamans, the Indian mainland, other British colonies and North America - I have been concerned with the relationship between the local and the global in histories of Empire. Through writing indigenous lives a new perspective on colonialism emerges, and some of the most marginalized peoples of Empire rightly occupy center ground in asking some of the most important questions of imperial history.

\section{ENDNOTES}

This article was written as part of the ESRC funded collaborative project "Integrated Histories of the Andaman Islands" (award no. RES-000-22-3484). I thank the ESRC and my Indian coinvestigators Madhumita Mazumdar and Vishvajit Pandya for their support. I am also grateful to Francis Xavier, and to archivists and staff in the Cellular Jail Museum Library, Port Blair; Duke University Library; National Archives of India (NAI); and India Office records collections of the British Library (IOR). Note that I parenthesize the British given names of Andaman islanders on their first mention in the text, in order to lay stress on their colonial origin.

${ }^{1}$ Clare Anderson, The Indian Uprising of 1857-8: prisons, prisoners and rebellion (London, 2007), ch. 5. See also the important book Vishvajit Pandya, In The Forest: visual and material worlds of Andamanese history (1858-2006) (Lanham, Maryland, 2009), 75.

${ }^{2}$ Topsy features in Satadru Sen's fascinating recent work on settler-islander relations: Satadru Sen, Savagery and Colonialism in the Indian Ocean: Power, pleasure and the Andaman islanders (Abingdon, Oxon, 2010), passim.

${ }^{3}$ M.V. Portman, A History of Our Relations with the Andamanese, compiled from histories and travels, and from the records of the Government of India, Volume I (Calcutta, 1899), 476; M.V. Portman, A History of Our Relations with the Andamanese, compiled from histories and travels, and from the records of the Government of India, Volume II (Calcutta, 1899), 557-571. A travel narrative published in 1960 writes of the boy "Topsy": Suresh Vaidya, Islands of the Marigold Sun (London, 1960), 424. See also Sen, Savagery and Colonialism, 107.

${ }^{4}$ Memoranda relative to three Andamanese in the charge of Major Tickell, when deputy commissioner of Amherst, Tenasserim, in 1861 by Col. S. R. Tickell, 28 July 1863, enc. vocabulary of Andamanese words, as ascertained from CRUSOE and FRIDAY, Journal of the Asiatic Society of Bengal (1864), 167 (emphasis in original).

${ }^{5}$ Sarah Meer, Uncle Tom Mania: Slavery, Minstrelsy and Transatlantic Culture in the 1850s (Athens, Georgia, 2005), 111, 134, 157; "Harriet Beecher Stowe and "The Man That Was a Thing", in Henry Louis Gates Jr. and Hollis Robbins, eds., The Annotated Uncle Tom's Cabin (New York, 2007), xliii-xlvi.

${ }^{6}$ Elizabeth Kolsky, Colonial Justice in British India: White Violence and the Rule of Law (Cambridge, 2010). 20, 153.

${ }^{7}$ Edwin F. Forbes, journal and letter book 1861 - 1865, East Dixmont, Penobscot County, Maine 161pp, Duke University rare book, manuscript and special collections library (henceforth Forbes manuscript.) For a detailed discussion of Edwin Forbes, see Clare Anderson, Subaltern Lives (Cambridge, 2011), ch. 3.

${ }^{8}$ Martin Daunton and Rick Halpern, eds., Empire and Others: British encounters with indigenous peoples (Philadelphia, 1999).

${ }^{9}$ For elaborations on this theme, see Philip D. Morgan, "Encounters between British and 'indigenous' peoples, c. 1500 - c. 1800", in Daunton and Halper, eds., Empire and Others, 51-52; Greg Dening, Beach Crossings: voyaging across times, cultures and self (Philadelphia, 2004).

${ }^{10}$ Clare Anderson, "Colonization, kidnap and confinement in the Andamans penal colony, 17711864", Journal of Historical Geography, 37, 1 (2011): 68-81. 
11 Anderson, "Colonization, kidnap and confinement"; IOR P/188/67 (India public proceedings 14 March 1863): "Treacherous murder of an English seaman", further notes by superintendent R.C. Tytler, n.d.; IOR P/188/67 (India public proceedings 24 June 1863), Tytler to J.W.S. Wyllie, under secretary to government of India, 27 April 1863; IOR P/188/67 (India public proceedings 4 August 1863), Tytler to E.C. Bayley, secretary to government of India, 15 July 1863 . On nearidentical discourses that followed indigenous-settler violence in early colonial Australia, see Inga Clendinnen, Dancing With Strangers: Europeans and Australians at first contact (Cambridge, 2005).

12 IOR P/188/67 (India public proceedings 31 July 1863): Reverend Henry Corbyn to Tytler, 2 July 1863. My emphasis.

${ }_{13}$ IOR P/188/67 (India public proceedings 31 July 1863): Corbyn to Tytler, 2 July 1863.

${ }^{14}$ Anderson, "Colonization, kidnap and confinement", 79. See also IOR P/188/67 (India public proceedings 31 July 1863): Corbyn to Tytler, 2 July 1863.

15 "Narrative no. 2 by Mr Corbyn", reproduced in Portman, A History of Our Relations, Vol. I, 424-5. Portman, officer in charge of the Andamanese later in the nineteenth century, noted that he did not understand this reported speech. The original report is located in IOR P/188/67 (India public proceedings 31 July 1864): "Establishment of the Andaman Home on Ross Island."

16 "Narrative no. 2 by Mr Corbyn", 427.

17 Portman, A History of Our Relations, Vols I and 2, passim.

${ }^{18}$ This reflects the systemic use of violence in colonial India more generally, during this period. See Kolsky, Colonial Justice in British India.

19 "Narrative no. 2, by Mr Corbyn", 406.

20 "Narrative no. 2, by Mr Corbyn", 406.

${ }^{21}$ I explore issues around the representation of John Andaman in Clare Anderson, "Oscar Mallitte's Andaman Photographs, 1857-8", History Workshop Journal, 67 (2009): 153-172. See also Pandya, In The Forest, 17 (n. 2).

22 Portman, A History of Our Relations, Vol. II, 557-561, 656-657, 659-660, 666-667, 681-682, 692693.

${ }^{23}$ IOR P/188/67 (India public proceedings 3 November 1863): Corbyn to Tytler, 3 October 1863; Friend of India, 5 December 1863.

24 "Narrative No. 3 by Mr. Corbyn", reproduced in Portman, A History of Our Relations, Vol. I, 448453.

${ }^{25}$ IOR P/188/67 (India public proceedings 15 April 1864): report of Reverend H. Corbyn, 1 March 1864.

${ }^{26}$ IOR P/188/66 (India public proceedings 28 March 1864): Tytler to Bayley, 8 February 1864. See also Portman, A History of Our Relations, Vol. II, 706-710.

${ }^{27}$ British officer in charge of the Andamanese E.H. Man later noted that mi'jola should be translated as "chief" or "elder": On the Aboriginal Inhabitants of the Andaman Islands, with report of researches in to the language of the South Andaman Islands (London, 1885), 26. However, "mijey-jeley" as used by Jarawa people in the Andamans today is more accurately translated as "friend." I thank Vishvajit Pandya for this information.

${ }^{28}$ IOR P/188/66 (India public proceedings 28 March 1864): Corbyn to Tytler, 12 February 1864.

${ }^{29}$ IOR P/188/66 (India public proceedings 28 March 1864): Tytler to Bayley, 8 February 1864.

${ }^{30}$ Portman, A History of Our Relations, Vol. I, 465, 472-3.

${ }^{31}$ IOR P/188/67 (India public proceedings 15 April 1864): Reports of Reverend H. Corbyn, 1 and 2 March 1864; J.W.S. Wyllie, under secretary to government of India, to superintendent Barnett Ford, 15 April 1864. See also Ford's response, reproduced in Portman, A History of our Relations, Vol. I, 472.

32 IOR P/188/66 (India public proceedings 24 August 1864): Corbyn to Ford, 21 June 1864.

33 Portman, A History of Our Relations, Vol. II, 866. See also Satadru Sen, "The orphaned colony: orphanage, child and authority in British India," Indian Economic and Social History Review, 44, 4 (2007): 484.

34 Portman, $A$ History of Our Relations, Vol. II, 870.

35 Portman, A History of Our Relations, Vol. II, 605, 60.

36 E.H. Man, "On the Andaman Islands, and their Inhabitants," Journal of the Anthropological Institute of Great Britain and Ireland, 14 (1885), 265.

${ }^{37}$ Man, On the Aboriginal Inhabitants of the Andaman Islands, xxi (n. 1).

${ }^{38}$ Portman, A History of Our Relations, Vol. II, 869. 
39 Portman, A History of Our Relations, Vol. II, 865-866, 868.

40 Portman, A History of Our Relations, Vol. II, 866, 869-70.

${ }^{41}$ Hastings Hadley D'Oyly was the grandson of Frederick Halliday, who had been appointed first lieutenant governor of Bengal in 1854. He appears to have been named in honor of Warren Hastings, the first governor-general of Bengal.

${ }^{42}$ Charles Mosley, ed., Burke's Peerage, Baronetage and Knightage, 107th edition, volume I, Wilmington, Delaware, U.S.A.: Burke's Peerage (Genealogical Books) Ltd, 2003, p. 1179. H.H. D. ${ }^{43}$ I am enormously grateful to Francis Xavier who took me to see this grave in the Port Blair cemetery.

${ }^{44}$ Unless indicated otherwise, the statements and correspondence cited in the discussion that follows are taken from: NAI Home (Port Blair A proceedings), May 1906, nos 37-49: Murder of Mrs D'Oyly. All the records in this file are in English (with the convict testimonies translated on the spot, written down in English from spoken Urdu statements, and read back to the convicts in Urdu for verification).

${ }^{45}$ Cf Kolsky, Colonial Justice in British India.

${ }^{46}$ NAI Home (Port Blair A proceedings) July 1906, nos 68-9: Rules regarding employing convicts as domestic servants.

${ }^{47}$ NAI Home (Port Blair A proceedings) October 1906, nos 25-6: Rules regarding domestic servants.

${ }^{48}$ NAI Home (Port Blair A proceedings) September 1906, nos 41-2: Extension of Mr D’Oyly's leave.

${ }^{49}$ Sugata Bose and Ayesha Jalal, Modern South Asia: History, Culture, Political Economy (London, 1998), 107-125.

50 Indrani Sen, "Colonial Domesticities, Contentious Interactions: Ayahs, Wed-Nurses and Memsahibs in Colonial India," Indian Journal of Gender Studies, 16 (2009): 299-328.

${ }^{51}$ Locally born, of mixed heritage.

${ }^{52}$ Anderson, Subaltern Lives, ch. 3.

${ }^{53}$ Sen, Savagery and Colonialism, 22.

54 Trevor Burnard, "Slave Naming Patterns: Onomastics and the Taxonomy of Race in EighteenthCentury Jamaica," Journal of Interdisciplinary History, 31, 3 (2001), 325-346. Examples from British India and the French Mascarene Islands are drawn from the author's unpublished research.

${ }^{55}$ Man, On the Aboriginal Inhabitants of the Andaman Islands, 173. 